\title{
Notes
}

\section{Popular Sovereignty, Double Jeopardy, and the Dual Sovereignty Doctrine}

\author{
Michael A. Dawson
}

In December 1953, a federal jury acquitted Alfonse Bartkus of robbing a federally insured bank. Because the Double Jeopardy Clause barred reprosecution of Bartkus in federal courts, the disappointed federal authorities instigated reprosecution of Bartkus by Illinois authorities under a state robbery statute. But the federal authorities did even more. They prepared the state case, guided the state prosecution, and postponed the sentencing of Bartkus' alleged coperpetrators until they testified against Bartkus at the state trial. ${ }^{1}$ In January 1954, Bartkus was tried in state court on substantially the same facts. This time, he was convicted and sentenced to life in prison. ${ }^{2}$

The Supreme Court affirmed Bartkus' conviction on two grounds: (1) the Double Jeopardy Clause did not apply to the states; ${ }^{3}$ and (2) even if the Double Jeopardy Clause were to apply to the states, offenses against different sovereigns are not the "same offense" for double jeopardy purposes. ${ }^{4}$ In 1969, the Court applied the Double Jeopardy Clause to the states, eviscerating the first ground for the decision in Bartkus. ${ }^{5}$ After 1969, cases following Bartkus relied solely on the second ground, the dual sovereignty doctrine. ${ }^{6}$ This doctrine alone

1. Bartkus v. Ilinois, 359 U.S. 121, 169 (1959) (Brennan, J., dissenting).

2. 359 U.S. at $164-68$ (Brennan, J., dissenting).

3. 359 U.S. at 124.

4. 359 U.S. at 128-29.

5. Benton v. Maryland, 395 U.S. 784 (1969).

6. See, e.g., Heath v. Alabama, 474 U.S. 82 (1985). 
justifies reprosecution by state authorities of defendants tried before federal courts, ${ }^{7}$ reprosecution by federal authorities of defendants tried before state courts, ${ }^{8}$ and reprosecution by state authorities of defendants tried before the courts of another state. ${ }^{9}$

This Note makes a new argument against the dual sovereignty doctrine. ${ }^{10}$ It argues that the doctrine is unconstitutional because it violates the principle of popular sovereignty underlying the Double Jeopardy Clause. This Note contends that the Double Jeopardy Clause should be understood not only as a protection afforded criminal defendants, but as a structural provision implementing the principle of popular sovereignty. This structural aspect of the Double Jeopardy Clause renders the dual sovereignty doctrine unconstitutional because it denigrates the power of the jury as well as the rights of criminal defendants. In short, this Note argues that the reprosecution of Alfonse Bartkus undermined the sovereignty of the people. In Bartkus, the people had spoken, acquitting the defendant, and exercising their ultimate check on government authority. The dual sovereignty doctrine allowed government to ignore this verdict, reprosecute Alfonse Bartkus, and undermine the sovereignty of the people.

\section{POPUlar SOVEREIGNTY}

Whenever the political laws of the United States are to be discussed, it is with the doctrine of the sovereignty of the people that we must begin.

-Alexis de Tocqueville ${ }^{11}$

The power of the people lies at the foundation of American government. ${ }^{12}$ In the United States, government derives its authority "from the consent of the governed"13 and maintains its legitimacy through the participation of the

7. Bartkus, 359 U.S. at 121 (1959) (permitting state prosecution for robbery following federal prosecution for robbery of federally insured bank).

8. Abbate v. United States, 359 U.S. 187 (1959) (permitting federal prosecution for conspiracy to destroy federal communications facilities following state prosecution for conspiracy to destroy property of another).

9. Heath, 474 U.S. 82 (permitting state prosecution for murder following murder prosecution by another state).

10. The unconstitutionality of the dual sovereignty doctrine is not, in itself, a novel claim. See generally Walter T. Fisher, Double Jeopardy, Two Sovereignties and the Intruding Constitution, 28 U. CHI. L. REV. 591 (1961); Harlan R. Harrison, Federalism and Double Jeopardy: A Study in the Frustration of Human Rights, 17 U. MIAMI L. REV. 306 (1963); Dominic T. Holzhaus, Double Jeopardy and Incremental Culpability: A Unitary Alternative to the Dual Sovereignty Doctrine, 86 COLUM. L. REV. 1697 (1986); Kenneth M. Murchison, The Dual Sovereignty Exception to Double Jeopardy, 14 N.Y.U. REV. L. \& Soc. CHANGE 383 (1986); George C. Pontikes, Dual Sovereignty and Double Jeopardy, 14 CASE W. RES. L. REV. 700 (1963); Lawrence Newman, Double Jeopardy and the Problem of Successive Prosecution, 34 S. CAL. L. REV. 252 (1961).

11. 1 AleXIS DE TOCQUeVILle, DEMOCRACY IN AMERICA 55 (Phillips Bradley ed., 1945).

12. See generally Akhil R. Amar, Of Sovereignty and Federalism, 96 YALE L.J. 1429-66 (1987) (discussing the principle of popular sovereignty).

13. THE DECLARATION OF INDEPENDENCE para. 2 (U.S. 1776). 
people in a representative democracy ${ }^{14}$ Although the people delegate authority and confer legitimacy, they retain sovereignty. ${ }^{15}$ As sovereign, the people possess the final check on government authority. ${ }^{16}$

When we translate the principle of popular sovereignty from political rhetoric into a legal idea, the distinctions between delegating, legitimating, and supervising government authority become important. While all three relate to the power of the people, only the third-supervising-constitutes an exercise of popular sovereignty, strictly speaking. While delegating authority is essential to constituting a government, until a government is constituted the people have nothing over which to exercise their sovereignty. And while legitimating government authority through representative democracy is also important, this action entails participating in government rather than exercising control over it. Only by asserting their supervisory powers over government do the people exercise their sovereignty.

It is important to understand two related aspects of this supervisory power: (1) an exercise of popular sovereignty must take place from without the structure of government; and (2) an exercise of popular sovereignty must be final and unappealable.

First, an exercise of popular sovereignty must be "supra-legal." Popular sovereignty cannot take place from within the structure of government, for to confine exercises of popular sovereignty to a place or role within the government would subject the popular will to government processes, regulation, and even control. ${ }^{17}$ Because the popular will cannot be regulated and remain sovereign, an exercise of popular sovereignty must be "supra-legal."

Historically, the American people have demonstrated this "supra-legal" aspect of popular sovereignty through revolution, constitutional convention, and jury nullification. In revolution and convention, the people exercised their "right ... to alter or abolish" any form of government destructive of their inalienable rights. ${ }^{18}$ The American Revolution occurred from outside the structure of the British Empire: to exercise their right to abolish the government, the colonists found it necessary first to declare independence from British authority and to "dissolve the political bands which have connected them with another [people]."19 The constitutional convention also occurred from outside the governmental structure: to exercise their right to alter or abolish an ineffec-

14. See PaUl A. DAWSON, AMERICAN GOVERNMENT: InSTTIUTIONS, POLICIES, AND POLITICs 31-32 (1987) (discussing legitimating function of participatory democracy).

15. See Amar, supra note 12, at 1437 (discussing distinction in American political thought between authority and sovereignty).

16. Government authority is controlled in the first instance by a system of "checks and balances" within the government. We should not forget, however, the existence of a final check on government authority possessed by the people.

17. Popular sovereignty should not be confused with populist reform, which takes place through, if not within, existing structures of government.

18. THE DECLARATION OF INDEPENDENCE para. 2 (U.S. 1776).

19. Id. at para. 1 . 
tual government, the Framers found it necessary to ignore the requirement in the Articles of Confederation that any amendment be approved by all of the state legislatures. ${ }^{20}$ Jury nullification, too, is supra-legal: most jurisdictions refuse to instruct the jury that they have this authority. ${ }^{21}$ The jury must itself determine that it possesses such power. Furthermore, this determination and the decision to exercise it quite literally occur outside the structure of government-that is, outside the courtroom in the jury room, from which the government is excluded.

The exercise of popular sovereignty must also be final and unappealable. In the words of James Wilson, "In all governments, whatever is their form, however they may be constituted, there must be a power established from which there is no appeal ... The only question is where that power is lodged? ... [I]t remains and flourishes with the people." ${ }^{.22}$ The final and unappealable aspect of popular sovereignty follows from the requirement that an exercise of popular sovereignty occur from without the structure of government. Once appeal is permitted, the following questions arise: Who may appeal? Before whom? How many times? Who may limit appeals? It is impossible to answer these questions without subjecting the popular will to government authority. Because an exercise of popular sovereignty must occur from without the ambit of government authority, such an exercise must be final and unappealable.

\section{The Double Jeopardy Clause:}

\section{IMPLEMENTING THE PRINCIPLE OF POPULAR SOVEREIGNTY}

... nor shall any person be subject for the same offense to be twice put in jeopardy of life or limb. ${ }^{23}$

The Double Jeopardy Clause has a distinguished pedigree. It is "the oldest of all the Bill of Rights guarantees," ${ }^{, 24}$ recognized in one form or another by "all the cultures from which we draw our moral and legal precepts."25 Con-

20. See Akhil R. Amar, Philadelphia Revisited: Amending the Constitution Outside Article V, 55 U. CHI. L. REV. 1043, 1047-56 (1988) (discussing process of ratification outside of Article $V$ and analogous provisions of state constitutions); $c f$. BRUCE ACKERMAN, WE THE PEOPLE: FOUNDATIONS 173-75 (1991) (discussing "illegality" of Constitutional Convention).

21. See United States v. Dougherty, 391 U.S. 145 (1968).

22. GORdON S. WOOD, THE CREATION OF THE AMERICAN REPUBLIC 530 (1969) (quoting JAMES WILSON, PENNSYLVANIA AND THE FEDERAL CONSTITUTION, 1787-88 (John Bach McMaster \& Frederick Dawson Stone eds., 1888)).

23. U.S. CoNST. amend. V. 828.

24. See George C. Thomas, II, An Elegant Theory of Double Jeopardy, 1988 U. ILL. L. REV. 827,

25. Id.; see generally Peter Westen \& Richard Drubel, Toward a General Theory of Double Jeopardy, 1978 SUP. CT. REV. 81; Comment, Twice in Jeopardy 75 YALE L.J. 262 (1963). 
cepts similar to the Double Jeopardy Clause may be found in the law of Athens, ${ }^{26}$ the law of the Roman Republics, ${ }^{27}$ the Digest of Justinian, ${ }^{28}$ early canon law, ${ }^{29}$ English common law, ${ }^{30}$ and early American colonial law. ${ }^{31}$

A distinguished pedigree can inhibit thought, however, tempting scholars to synthesize millennia of double jeopardy jurisprudence into a simple rubric. An example of a work that attempts this synthesis is Twice in Jeopardy. ${ }^{32}$ Appearing in 1963 as the Warren Court was reaching its "apogee,"33 this student comment synthesized double jeopardy jurisprudence into a framework grounded in individual rights. In so doing, Twice in Jeopardy organized the whole of Double Jeopardy jurisprudence around three rules: "the rules which bar retrial for the same offense after acquittal, retrial for the same offense after conviction, and multiple punishment for the same offense at one trial. ${ }^{\prime 34}$

Twice in Jeopardy has influenced thinking about the Double Jeopardy Clause by courts ${ }^{35}$ and commentators ${ }^{36}$ for decades. Its rules-oriented approach proved highly compatible with the individual rights-oriented jurisprudence of the Warren Court. Yet Twice in Jeopardy regards the Double Jeopardy Clause as merely the modern version of an ancient legal precept. It ignores the distinctly American innovations imparted to the precept when it was incorporated into the United States Constitution. Because the work fails to evaluate the Double Jeopardy Clause as an integral part of the Bill of Rights and the Constitution, Twice in Jeopardy fails to appreciate the structural purpose of the Double Jeopardy Clause. As a result, it reduces double jeopardy jurisprudence to nothing more than a menu of procedural safeguards afforded criminal defendants.

A second seminal work moved beyond the rules-oriented approach of Twice in Jeopardy to examine the interests underlying the Double Jeopardy Clause but, like Twice in Jeopardy, failed to appreciate fully the structural role of the

26. Thomas, supra note 24 , at 836 (citing JOHN WALKER JONES, LAW AND LEGAL THEORY OF THE GREEKS 148 (1956)).

27. JaY A. Sigler, Double Jeopardy: THE DEVElopment of a Legal and SOCLal POlicy 2-3 (1969); JAMES LEIGH STRACHAN-DAVIDSON, PROBLEMS OF THE ROMAN CRIMINAL LAIV 155 (1912).

28. DIG. 48.2.7.2 (Ulpian, Officio Proconsulis 7).

29. See Bartkus v. Ilinois, 359 U.S. 121, 152 n.4 (1959) (Black, J., dissenting) (describing "canon law opposition to double trials" manifest, inter alia, in the maxim "Not even God judges twice for the same act").

30. See 4 WILlam Blackstone, COMMEnTaRIES *328-29.

31. See Bartkus, 359 U.S. at 153 n.7 (Black, J., dissenting) (citing American colonial law prohibiting double jeopardy).

32. Twice in Jeopardy, supra note 25.

33. Owen Fiss, A Life Lived Twice, 100 YaLE L.J. 1117, 1117 (1991).

34. Twice in Jeopardy, supra note 25 , at 265-66 (citations omitted). Under narrowly prescribed circumstances, a fourth rule bars retrial following a mistrial. Id. at 266.

35. See, e.g., North Carolina v. Pearce, 395 U.S. 711, $717 \mathrm{n.8}$ (1969) (citing Twice in Jeopardy in opinion holding that Double Jeopardy Clause does not bar imposition of heavier sentence upon reprosecution following erroneous conviction).

36. See, e.g., Thomas supra note 24 (presenting Twice in Jeopardy as one of three dominant paradigms in Double Jeopardy jurisprudence). 
Clause. In Toward a General Theory of Double Jeopardy, ${ }^{37}$ Peter Westen and Richard Drubel argued that "the principle of double jeopardy serves three interests. In ascending degrees of importance, they are: (1) an interest in finality ... (2) an interest in avoiding double punishment ... and (3) an interest in protecting nullification-viz., an interest in allowing the system to acquit against the evidence. . . ."38 Under their analysis, the Double Jeopardy Clause was no longer reduced to a mere menu of procedural safeguards afforded criminal defendants. Indeed, Westen and Drubel downplayed the individual rights aspect of the Clause: though the interest in finality is based largely in a concern for the rights of criminal defendants, ${ }^{39}$ Westen and Drubel argue that finality is a weak value, "insufficient, by itself, to explain results reached in double jeopardy cases." ${ }^{, 40}$ In addition, Westen and Drubel developed two structural aspects of the Double Jeopardy Clause: (1) subjecting prosecutors to constraints imposed by legislatures; and (2) subjecting prosecutors to constraints imposed by juries.

The interest in avoiding double punishment assures that prosecutors respect the will of legislatures. This interest reflects a concern that a defendant not be subject to punishment greater than that intended by the legislature. ${ }^{41}$ Where punishment is not specifically prescribed but left to the discretion of a judge, the interest in avoiding double punishment ensures that this discretion is exercised within limits prescribed by the legislature. ${ }^{42}$ Under the analysis of Westen and Drubel, avoiding double punishment is an important value. Indeed, the value is promoted by two rules: the rule against reprosecution for the same offense after conviction and the rule against multiple punishment for the same offense at one trial. ${ }^{43}$ Further, the language of the original Double Jeopardy

\footnotetext{
37. Westen \& Drubel, supra note 25.

38. Id. at 84 .

39. Justice Black captured the value of finality in an oft-cited passage:

The constitutional prohibition against "double jeopardy" was designed to protect an individual from being subjected to the hazards of trial and possible conviction more than once for an alleged offense. . . . The underlying idea, one that is deeply ingrained in at least the AngloAmerican system of jurisprudence, is that the state with all its resources and power should not be allowed to make repeated attempts to convict an individual for an alleged offense, thereby subjecting him to embarrassment, expense and ordeal and compelling him to live in a continuing state of anxiety and insecurity, as well as enhancing the possibility that even though innocent he may be found guilty.
}

Green v. United States, 355 U.S. 184, 187-88 (1957) (reversing conviction for first degree murder following conviction for second degree murder).

40. Westen \& Drubel, supra note 25 , at 105-06. But see Thomas, supra note 24 , at $831-32$ (contending that all three values commonly supposed to be advanced by Double Jeopardy Clause may be reduced to one: "verdict finality").

41. Ex parte Lange, 85 U.S. (18 Wall.) 163, 168 (1873) (discharging habeas petitioner sentenced beyond statutory authorization); see generally, Westen \& Drubel, supra note 25, at 107-11.

42. North Carolina v. Pearce, 395 U.S. 711, 718-20 (1969) (holding that prison term served following conviction later held erroneous plus prison sentence imposed upon successive prosecution may not together exceed punishment authorized by statute).

43. See supra text accompanying note 34 . 
Clause proposed by Madison shows that avoiding double punishment was prominent in the minds of the Framers. ${ }^{44}$

The interest in protecting nullification ensures that prosecutors respect the will of juries. ${ }^{45}$ Nullification is the jury's power to acquit against the evidence. Since juries need not explain their verdicts, it may be difficult to distinguish an instance of nullification from an ordinary acquittal. To protect the power of nullification, therefore, reprosecutions following acquittals generally must be prohibited. ${ }^{46}$ Having failed to convince a jury of the defendant's guilt, prosecutors may not simply impanel a new jury and try again.

But Toward a General Theory of Double Jeopardy, like Twice in Jeopardy, fails to recognize the distinctly American innovations imparted to the Double Jeopardy Clause when it was incorporated into the United States Constitution. Because the work failed to evaluate the Double Jeopardy Clause as an integral part of the Bill of Rights and the Constitution, Toward a General Theory of Double Jeopardy fails to link the interest in protecting the power of nullification to the role of the Double Jeopardy Clause in implementing the principle of popular sovereignty.

Further analysis reveals that the interest in protecting the power of juries is even more central than Westen and Drubel suggest. Westen and Drubel associate the interest in protecting nullification with the rule barring reprosecution after acquittal. This interest, however, is associated not only with that rule, but also with the rule barring reprosecution after conviction. Where multiple charges are contained in the indictment, conviction for a lesser offense may entail an implicit acquittal of the greater offense. ${ }^{47}$ As with explicit acquittals, an implicit acquittal may be an instance of nullification or an instance of an ordinary acquittal. Having failed to convince a jury to convict the defendant of the greater offense, prosecutors may not try again with a new jury. Even where the jury convicts on all charges that are presented to it in the indictment, one may assume that the prosecutor did not bring more serious charges because he or she predicted that the jury would acquit the defendant of those charges. ${ }^{48}$ As in the case of explicit acquittals, having obtained a conviction on a lesser charge and an implicit acquittal on a greater charge, the prosecutors may not reprosecute the defendant on the greater charge. ${ }^{49}$

44. The original version of the Double Jeopardy Clause, as proposed by Madison, read, "No person shall be subject, except in cases of impeachment, to more than one punishment or trial for the same offense." 1 ANNALS OF CONG. 434 (Joseph Gales ed., 1789). See infra text accompanying notes 56-60.

45. See Westen \& Drubel, note 25 at 129-30; see generally United States v. Ball, 163 U.S. 662, 670-71 (1896) (relying on nullification to reverse conviction following acquittal); Alan W. Scheflin, Jury Nullification: The Right to Say No, 45 S. CAL. L. REV. 168 (1972).

46. See supra text accompanying note 34 .

47. Green v. United States, 355 U.S. 184, 191 (1957) (finding defendant convicted of second degree murder implicitly acquitted of first degree murder).

48. In such circumstances a prosecutor will decline to include the more serious charges for fear of creating a perception of overreaching and weakening his or her case on the less serious charges.

49. See Green, 355 U.S. 184. 
The structural role of the Double Jeopardy Clause can be understood by considering the Clause in conjunction with other provisions of the Bill of Rights and with the Constitution itself. The Bill of Rights contains three amendments expressly concerned with juries. The Fifth Amendment sets out the requirement of a grand jury in criminal cases, ${ }^{50}$ the Sixth guarantees the right to a petit jury in a criminal trial, ${ }^{51}$ and the Seventh requires a jury in certain civil cases. ${ }^{52}$ In each case, juries serve the role of "populist protectors," to exert popular local control over the federal government. Consider, for example, the words of de Tocqueville:

The institution of the jury ... places the real direction of society in the hands of the governed, .... and not in that of the government. ... [It] invests the people, or that class of citizens, with the direction of society. . . . The jury system as it is understood in America appears to me to be as direct and as extreme a consequence of the sovereignty of the people as universal suffrage. They are two instruments of equal power, which contribute to the supremacy of the majority. ${ }^{54}$

Legislatures may proscribe, executives may prosecute, and judges may preside only to have their statutes, closing statements, and jury charges disregarded by the peers of the accused. By, exercising their power to acquit against the evidence, twelve angry citizens may be the last check on governmental authority. 55

Article I of the Constitution and the original language of the Double Jeopardy Clause further reveal the principle of popular sovereignty underlying the Double Jeopardy Clause. The power of impeachment, though ostensibly an exception to the Double Jeopardy Clause, actually reinforces the principle of popular sovereignty. The double jeopardy guarantee originally proposed by James Madison read, "No person shall be subject, except in cases of impeachment, to more than one punishment or trial for the same offense." 56 The phrase "except in cases of impeachment" did not make it into the final version of the Double Jeopardy Clause. Presumably, however, it was irrelevant. Article I, Section 3 of the Constitution provides,

50. U.S. CONST. amend. V ("No person shall be held to answer for a capital, or otherwise infamous crime, unless on a presentment or indictment of a Grand Jury. ....").

51. U.S. CONST. amend. VI ("In all criminal prosecutions, the accused shall enjoy the right to a speedy and public trial, by Jury ....").

52. U.S.CONST. amend. VI ("In suits at common law, where the value in controversy shall exceed twenty dollars, the right of trial by jury shall be preserved, and no fact tried by a jury shall otherwise be reexamined in any Court of the United States, than according to the rules of the common law").

53. See Akhil R. Amar, The Bill of Rights as a Constitution, 100 YALE L.J. 1131, 1183-85 (1991).

54. 1 ALEXIS DE TOCQUEVILLE, supra note 11 , at $282-83$ (quoted in id. at 1185).

55. In the Roman Republics, verdicts of acquittal were subject to appeal only before the general assembly. See Thomas, supra note 24, at 836 n.64 (citing 1 STRACHAN-DAVIDSON, supra note 27, at 155).

56. 1 ANNALS OF CoNG. 434 (Joseph Gales ed., 1789). 
The Senate shall have the sole Power to try all Impeachments. . . . Judgment in Cases of Impeachment shall not extend further than to removal from Office, and disqualification to hold and enjoy any Office or honor, Trust or Profit under the United States: but the Party convicted shall nevertheless be liable and subject to Indictment, Trial, Judgment and Punishment, according to Law. ${ }^{57}$

Thus, the text of the Constitution provides that office holders convicted by the Senate remain subject to criminal prosecution for the offenses on which their impeachment conviction was based.

Before the Senate may try an impeachment, however, the House of Representatives must impeach. ${ }^{58}$ The House of Representatives, through biennial elections and sheer numbers, is the branch closest to the people. By limiting the impeachment exception to the Double Jeopardy Clause to circumstances in which the House of Representatives has acted, the exception respects the principle of popular sovereignty. ${ }^{59}$

Considering the Double Jeopardy Clause with other provisions of the Bill of Rights and as part of the Constitution forces the recognition that the Clause is more than a modern version of an ancient legal precept. The Double Jeopardy Clause is also a structural provision implementing the principle of popular sovereignty. ${ }^{60}$

\section{THE DUAL SOVEREIGNTY DOCTRINE}

As discussed above, Bartkus v. Illinois held that the Double Jeopardy Clause did not prohibit prosecution by state authorities of a person who had been subjected previously to federal prosecution for the same offense. ${ }^{61}$ Abbate v. United States, ${ }^{62}$ a companion case, held the converse: the Double Jeopardy Clause did not prohibit prosecution by federal authorities of a person who had been subjected previously to state prosecution for the same offense. Both decisions rested on the same two grounds. First, the Double Jeopardy Clause

57. U.S. CONST. art. I, $\S 3$.

58. U.S. CONST. art. I, $\$ 2$ (providing that "The House of Representatives ... shall have the sole Power of Impeachment").

59. Under the Seventeenth Amendment, the impeachment trial, in addition to the recommendation to impeach, is directed by a tribunal that is relatively close to the people. See U.S. CONST. amend XVII (providing for popular election of Senators). Thus, the Seventeenth Amendment strengthens the argument that the impeachment exception to the Double Jeopardy Clause affirms the principle of popular sovereignty underlying the Clause.

60. Even if other double jeopardy principles implement versions of the principle of popular sovereignty, the concept of popular sovereignty implemented by the Double Jeopardy Clause is uniquely American. See Amar, supra note 12, at 1432 (distinguishing conception of popular sovereignty implemented by Constitution from earlier notions of popular sovereignty).

61. See supra text accompanying notes 3-4.

62. 359 U.S. 187 (1959) (permitting federal prosecution for conspiracy to destroy federal property following state prosecution for conspiracy to destroy property of another). 
did not apply to the states. ${ }^{63}$ Second, under the dual sovereignty doctrine, offenses against different sovereigns were not the "same offense" for double jeopardy purposes. ${ }^{64}$

Before 1969, the Double Jeopardy Clause did not apply to the states. Indeed, the Supreme Court specifically rejected the argument that the Fourteenth Amendment made the Double Jeopardy Clause applicable to the states in Palko v. Connecticut. ${ }^{65}$ The Court reasoned that the Double Jeopardy Clause was not so fundamental as to warrant application to the states. Only in cases of "acute and shocking" hardship would the Court prohibit double jeopardy by the states-and then under the rubric of due process. ${ }^{66}$

In 1969, Benton v. Maryland ${ }^{67}$ overturned Palko. The Benton Court termed the Double Jeopardy Clause "a fundamental ideal in our constitutional heritage," so essential as to require application against the states. ${ }^{68}$ After Benton, the Double Jeopardy Clause prohibited prosecution by state authorities of a person who previously had been subjected to state prosecution for the same offense. Benton eviscerated the first ground of the decisions in Bartkus and Abbate. After Benton, cases following Bartkus and Abbate could rely only on the dual sovereignty doctrine. ${ }^{69}$ To the history of that doctrine this Note now turns.

\section{A. The History of the Dual Sovereignty Doctrine}

The dual sovereignty doctrine derives from the common law notion that a crime is an offense against the sovereign. Where an act violates the criminal prohibitions of both a state and the United States, the act gives rise to two distinct offenses: one against the state and one against the United States. Because the Double Jeopardy Clause protects defendants from successive prosecutions for the same offense, prosecution of offenses against different sovereigns is not barred by the Double Jeopardy Clause, even where the offenses are defined by identical statutory language.

The early cases developing the dual sovereignty doctrine were not concerned with successive prosecutions by state and federal authorities. Rather, they concerned shared state and federal legislative authority to criminalize certain conduct. In a series of cases in the late nineteenth and early twentieth centuries, the constitutional validity of federal crimes was challenged with the following argument:

\footnotetext{
63. Bartkus, 359 U.S. at 124.

64. Id. at 128-29.

65. 302 U.S. 319,322 (1937).

66. Id. at 328.

67. 395 U.S. 784 (1969) (applying Double Jeopardy Clause to states).

68. Id. at 794-95.

69. See, e.g., Heath v. Alabama, 474 U.S. 82 (1985).
} 
1) criminal law had traditionally been the province of the states;

2) competence to criminalize conduct must be exclusive;

3) federal crimes in areas traditionally criminalized by the states would result in shared state and federal competence;

4) therefore, federal crimes in areas traditionally criminalized by the states were unconstitutional. ${ }^{70}$

The dual sovereignty doctrine was developed to meet this argument. ${ }^{71}$ Criminal competence need not be exclusively the province of state or federal law. It may be shared, proponents of the doctrine argued. These cases did not hold that the Double Jeopardy Clause permitted successive prosecution by separate sovereigns. Rather, the cases merely rejected the idea that the Clause rendered unconstitutional federal statutes criminalizing conduct traditionally criminalized by the states.

Early cases rejected challenges to state convictions on the grounds that the conviction punished conduct over which the Congress had legislative jurisdiction. In these cases, defendants had argued that exposing them to the mere possibility of a successive prosecution by federal authorities violates the Double Jeopardy Clause. The Court rejected these arguments. ${ }^{72}$ In Moore v. Illinois, the Court wrote,

The same act may be an offence or transgression of the laws of [Illinois and the United States]. . . . That either or both may (if they see fit) punish such an offender, cannot be doubted. Yet it cannot be truly averred that the offender has been twice punished for the same offence; but only that by one act he has committed two offences, for each of which he is justly punishable. ${ }^{73}$

Because a federal prosecution had not, in fact, been brought in Moore, this statement was dicta. In cases in which the defendant challenged a conviction on grounds that an earlier prosecution by another sovereign had actually been brought, the Court upheld the conviction on grounds that the statutes prohibited different types of behavior and protected different interests. ${ }^{74}$ It was not until

70. See, e.g., infra note 71 .

71. See, e.g., Moore v. Illinois, 55 U.S. (14 How.) 13 (1852) (rejecting argument that possibility of successive prosecution by federal authorities invalidated conviction by state authorities).

72. See Gilbert v. Minnesota, 254 U.S. 325 (1920) (rejecting argument that possibility of successive prosecution by federal authorities invalidated conviction by state authorities); Crossley v. California, 168 U.S. 640 (1898) (same); Cross v. North Carolina, 132 U.S. 131 (1889) (same); Moore, 55 U.S. at 13 (same); see also McKelvey v. United States, 260 U.S. 353 (1922) (rejecting argument that possibility of successive prosecution by state authorities invalidated conviction by federal authorities); Ex parte Siebold, 100 U.S. 371 (1879) (same); United States v. Cruikshank, 92 U.S. 542 (1875) (same).

73. 55 U.S. at 20 (upholding conviction for violation of state fugitive slave law notwithstanding existence of federal fugitive slave law).

74. Pettibone v. United States, 148 U.S. 197, 209 (1893) (upholding federal conviction for conspiracy to violate injunction against intimidating mine managers into discharging employees following state conviction for conspiracy to intimidate mine managers into discharging employees). 
United States $v$. Lanza ${ }^{75}$ that the dual sovereignty doctrine was used to permit prosecution by one sovereign after prosecution by another. ${ }^{76}$ In Lanza, the Court permitted federal prosecution for violation of the National Prohibition Act following state prosecution and conviction for violation of state Prohibition laws. In so holding, the Court relied on the dual sovereignty doctrine:

We have here two sovereignties, deriving power from different sources, capable of dealing with the same subject-matter within the same territory. ... Each government, in determining what shall be an offense against its peace and dignity is exercising its own sovereignty, not that of the other. It follows that an act denounced as a crime by both national and state sovereignties is an offense against the peace and dignity of both and may be punished by each. ${ }^{77}$

Under this doctrine, proscriptions emanating from different "sovereigns" are different offenses. Because the Double Jeopardy Clause only prohibits successive prosecutions for the "same offense," successive prosecutions by different sovereigns are not barred by the Clause.

The holding in Lanza might seem limited to successive prosecutions for state and federal offenses prescribed pursuant to the Eighteenth Amendment. Section 2 of that Amendment provides, "[t]he Congress and the several States shall have concurrent power to enforce this article by appropriate legislation." authority to "exercise an independent judgment in selecting and shaping measures to enforce prohibition." eignty doctrine was limited to areas of law over which states and Congress share legislative authority pursuant to constitutional mandate.

Any idea that the dual sovereignty doctrine depended upon the existence of a constitutional mandate of shared state and federal legislative competence, however, was repudiated by the Lanza court itself. Following his reference to the Eighteenth Amendment, Chief Justice Taft wrote, "To regard the [Eighteenth] Amendment as the source of the power of the states to adopt and enforce prohibition measures is to take a partial and erroneous view of the matter." ${ }^{\prime 80}$ Chief Justice Taft made clear that the authority of states to legislate flows not from the Eighteenth but from the Tenth Amendment. ${ }^{81}$ As if this disclaimer were not enough, the dual sovereignty doctrine survived repeal of the Eighteenth Amendment. This survival removed any remaining possibility

75. 260 U.S. 377 (1922). Lanza).

76. See Pontikes, supra note 10 , at 706-10 (discussing development of dual sovereignty doctrine before

77. Lanza, 260 U.S. at 382.

78. U.S. CONST. amend. XVIII.

79. Lanza, 260 U.S. at 381.

80. Id.

81. Id. at 382 . 
that the dual sovereignty doctrine was premised merely upon a constitutional mandate of concurrent state and federal authority to criminalize certain types of conduct. . $^{82}$

Ironically, Chief Justice Taft identified the Tenth Amendment as the source of the dual sovereignty doctrine: "The powers not delegated to the United States by the Constitution, nor prohibited by it to the States, are reserved to the States. . . ."83 In so doing, Taft ignored the last four words of the Amendment: "or to the people." 84 Thus, while the Tenth Amendment is the source for the dual sovereignty doctrine, it reaffirms the principle of popular sovereignty that the Double Jeopardy Clause is designed to implement.

The dual sovereignty doctrine has not been without its critics. Not only has the constitutionality of the doctrine been questioned by scholars; ${ }^{85}$ federal and state authorities have limited the reach of the doctrine via internal policies or legislation. For example, the dual sovereignty doctrine has been limited somewhat by the Justice Department's "Petite Policy"86 and by various state statutes. ${ }^{87}$ The Petite Policy was announced by the Attorney General shortly after Bartkus, in Petite v. United States. ${ }^{88}$ Under the policy, the federal government will not prosecute a defendant who has been previously prosecuted in a state court for the same conduct unless "compelling interests" support a second prosecution. ${ }^{89}$

The Petite Policy is an incomplete limitation on federal prosecution following state prosecution, however. The policy is invoked at the government's discretion. It does not confer upon those prosecuted for state crimes the right to challenge a subsequent federal prosecution in violation of the policy. ${ }^{90}$ Cases in which the Supreme Court vacated and remanded convictions under the Petite Policy have been disposed of by per curiam $\operatorname{order}^{91}$ so as to avoid

82. Although the Eighteenth Amendment is not the source of the dual sovereignty doctrine, the context of Prohibition is important to understanding one of the (often implicit) rationales for the doctrine. This rationale is reflected in Chief Justice Taft's concern that "[i]f a State were to punish the manufacture, transportation and sale of intoxicating liquor by small or nominal fines, the race of offenders to the courts of that State to plead guilty and secure immunity from federal prosecution for such acts would not make for respect for the federal statute or for its deterrent effect." Id. at 385. The concern that state courts could immunize defendants from federal prosecution seems particularly pressing in the context of federal enforcement of the civil rights laws. As will be discussed below, however, the concern that state courts might immunize defendants from federal prosecution does not cure the constitutional defects in the dual sovereignty doctrine. See infra text accompanying notes 139-142.

83. Lanza, 260 U.S. at 382.

84. U.S. CONST. amend. $X$.

85. See supra note 10.

86. See Dual Prosecution and Successive Federal Prosecution Policies, in UNTED STATES ATTORNEY'S MANUAL 9-2.142 (1980) (limiting federal prosecutions following state prosecutions to situations implicating "compelling interests").

87. See infra text accompanying notes $94-96$.

88. 361 U.S. 529 (1960).

89. Id.

90. See Rinaldi v. United States, 434 U.S. 22, 31 (1977) (per curiam) (conditioning defendant's benefit under the Petite Policy on the government's invocation of that policy).

91. See, e.g., Watts v. United States, 422 U.S. 1032 (1975), vacating 505 F.2d 951 (5th Cir. 1974); 
creating any impression of the existence of a "right of criminal defendants to obtain enforcement of the policy." 92 Furthermore, while the policy limits the instances of federal prosecutions following state prosecutions, such prosecutions are brought routinely. ${ }^{93}$

Twenty-three states have adopted statutes limiting the dual sovereignty doctrine. ${ }^{94}$ However, the limitation effected by these statutes is even less complete than that effected by the Petite Policy. The Petite Policy limits federal prosecution of offenses arising out of the same conduct previously subject to state prosecutions. Thirteen states impose a similar limitation, limiting state prosecution of offenses arising out of the same conduct previously subject to federal prosecution. ${ }^{95}$ Another seven states limiting the dual sovereignty doctrine, however, do so by limiting reprosecution for the same offense-not for the same conduct. ${ }^{96}$ As in the case of federal prosecutions following state prosecutions, state prosecutions following federal prosecutions for offenses arising from the same conduct are brought routinely. ${ }^{97}$

\section{B. The Curious Longevity of the Dual Sovereignty Doctrine}

The incorporation of the various provisions of the Bill of Rights against the states has led to the demise of doctrines like the dual sovereignty doctrine, doctrines that allowed cooperating state and federal prosecutors to do what

Ackerson v. United States, 419 U.S. 1099 (1975), vacating 502 F.2d 300 (8th Cir. 1974); Hayles v. United States, 419 U.S. 892 (1974), vacating 492 F.2d 125 (5th Cir. 1974); Thompson v. United States, 400 U.S. 17 , vacating 421 F.2d 373 (5th Cir. 1970).

92. Delay v. United States, 602 F.2d 173, 176 (8th Cir. 1979) (denying Double Jeopardy claim premised on violation of Petite Policy).

93. See, e.g., United States v. Simpkins, 953 F.2d 443 (8th Cir. 1992); United States v. Paiz, 905 F.2d 1014 (7th Cir. 1990); United States v. Bartlett, 856 F.2d 1071 (8th Cir. 1988); United States v. Bernhardt, 831 F.2d 181 (9th Cir. 1987); United States v. Aboumoussallem, 726 F.2d 906 (2d Cir. 1984).

94. ALA. CODE $§ 15-3-8$ (1975); ALASKA STAT. $\$ 12.20 .010$ (1962); ARK. CODE ANN. $\$ 5-1-114$ (Michie 1987); CAL. PENAL CODE $\$ 656$ (West 1988); DEL. CODE ANN. tit. 11, $\$ 209$ (1987); GA. CODE ANN. \$ 16-1-8(c) (Michie 1988); HAW. REV. STAT. § 701-112 (1988); IDAHO CODE \$ 19-315 (1947); ILL. ANN. STAT. ch. 38, para. 3-4(c) (Smith-Hurd 1961); IND. CODE ANN. § 35-41-4-5 (Bums 1985); KY. REV. STAT. ANN. $\$ 505.050$ (Baldwin 1990); MINN. STAT. $\S 609.045$ (1987); MISS. CODE ANN. $\$ 99-11-27$ (1972); MONT. CODE ANN. \$ 46-11-504 (1989); N.J. REV. STAT. \$ 2C:1-11 (1982); N.Y. CRM1. PROC. LAW $\S 40.10$ to 40.30 (McKinney 1992); N.D. CENT. CODE § 29-03-13 (1960); OKLA. STAT. ANN. tit. 21, § 25 (West 1983); 18 PA. CONS. STAT. \$ 111 (1983); UTAH CODE ANN. § 76-1-404 (1990); VA. CODE ANN. § 19.2-294 (Michie 1990); WASH. REV. CODE ANN. § 10.43 .040 (West 1961); WIS. STAT. ANN. § 939.71 (West 1958).

95. Ala. Code $\$ 15-3-8$ (1975); Alaska STAT. $\$ 12.20 .010$ (1962); CaL. PENAL CODE $§ 656$ (West 1988); IDAHO CODE § 19-315 (1947); IND. CODE ANN. § 35-41-4-5 (Burns 1985); MONT. CODE ANN. § 4611-504 (1989); N.Y. CRIM. PROC. LAW \$ 40.10 to 40.30 (McKinney 1992); N.D. CENT. CODE § 29-03-13 (1960); OKLA. STAT. ANN. tit. 21, § 25 (West 1983); UTAH CODE ANN. \$ 76-1-404 (1990); VA. CODE ANN. § 19.2-294 (Michie 1990); WASH. REV. CODE ANN. § 10.43.040 (West 1961); WIS. STAT. ANN. § 939.71 (West 1958).

96. ARK. CODE ANN. § 5-1-114 (Michie 1987); DEL. CODE ANN. tit. 11, § 209 (1987); HAW. REV. STAT. § 701-112 (1988); MNN. STAT. § 609.045 (1987); MISS. CODE ANN. § 99-11-27 (1972); N.J. REV. STAT. § 2C:1-11 (1982); 18 PA. CONS. STAT. \$ 111 (1983).

97. See, e.g., People v. Covelli, 540 N.E.2d 569 (11l. 1989), appeal denied, 545 N.E.2d 118 (11. 1989); Commonwealth v. Trignani, 483 A.2d 862 (Pa. 1984); State v. Caliguri, 664 P.2d 466 (Wash. 1983). 
neither was permitted to do independently. For example, under the "silver platter doctrine," federal authorities could use evidence seized by state authorities even when the evidence was seized pursuant to procedures that, had they been performed by federal authorities, would have violated the Fourth Amendment and therefore been suppressed..$^{98}$ Wolf $v$. Colorado $o^{99}$ foreshadowed the demise of the silver platter doctrine by holding that the Fourth Amendment's prohibition against unreasonable searches and seizures applied to the states through the Due Process Clause of the Fourteenth Amendment. In Elkins v. United States, ${ }^{100}$ the doctrine began to tarnish. Citing "expanding federal criminal jurisdiction," cooperation between state and federal law enforcement agencies, ${ }^{101}$ and the application of the Fourth Amendment to the states, ${ }^{102}$ the Court vacated a federal conviction based on evidence illegally obtained by state authorities. With application of the exclusionary rule to the states in Mapp v. Ohio, ${ }^{103}$ the Court dropped the doctrine altogether. A similar fate met arrangements between federal and state governments with respect to the use of coerced confessions. In Murphy v. Waterfront Commission, ${ }^{104}$ the Supreme Court overturned a previous case ${ }^{105}$ permitting the federal government to compel testimony possibly incriminating under state law. The incorporation of the Fifth Amendment privilege against self-incrimination ended one sovereign's use at trial of a confession coerced by another sovereign. ${ }^{106}$

Given the demise of these concepts, survival of the dual sovereignty doctrine after application of the Double Jeopardy Clause against the states seems anomalous. ${ }^{107}$ The only plausible explanation for the survival of the doctrine is that the silver platter doctrine (in both its Fourth and Fifth Amendment varieties) necessarily involves cooperation between state and federal authorities, while the dual sovereignty doctrine theoretically does not. Cooperation is always present when one sovereign offers illegally obtained evidence to another, but it need not be involved in successive prosecutions. In theory, the dual sovereignty doctrine does not apply when cooperation is so close that the two authorities must be viewed as a single sovereign.

98. See Weeks v. United States, 232 U.S. 383 (1914) (reversing federal conviction due to Fourth Amendment violations by federal officials but allowing consideration on remand of evidence seized by state officials without inquiry into legality of state seizure); Alan C. Kohn, Admissibility in Federal Court of Evidence Illegally Seized by State Officers, 1959 WASH. U. L.Q. 229.

99. 338 U.S. 25 (1945) (applying Fourth Amendment to states via Due Process Clause of Fourteenth Amendment).

100. 364 U.S. 206 (1960) (vacating federal conviction based on evidence illegally obtained by state officials).

101. Id. at 211 .

102. Id. at 213 .

103. 367 U.S. 643 (1961).

104. 378 U.S. 52 (1964).

105. United States v. Murdock, 284 U.S. 141 (1954).

106. See Murphy, 378 U.S. at 52.

107. See Note, Double Prosecution by State and Federal Governments: Another Exercise in Federalism, 80 HARV. L. REV. 1538, 1544-49 (1967) (arguing that Murphy presages decline of dual sovereignty
doctrine). 
Bartkus itself suggested such an exception to the dual sovereignty doctrine: the Double Jeopardy Clause would bar successive prosecutions where "the state prosecution was a sham and a cover for a federal prosecution, and thereby in essential fact another federal prosecution." 108 Following this suggestion, several courts have inferred from Bartkus a sham prosecution exception to the dual sovereignty doctrine. ${ }^{109}$ However, it is clear that the exception, if it exists at all, is "narrow." 110 Mere "cooperation between prosecutorial sovereignties" is not sufficient to meet the sham prosecution exception. ${ }^{111}$ Indeed, despite extensive state/federal cooperation in Bartkus itself, the Court did not remand on the question of a sham prosecution. The extensive cooperation catalogued by the dissent in Bartkus reveals how narrow is the exception. ${ }^{112}$

The sham prosecution exception is more than narrow, it is illusory. No double jeopardy claim premised on the sham prosecution exception to the dual sovereignty doctrine has survived appeal. ${ }^{113}$ This is true even under circumstances strongly suggesting a sham prosecution. In one case, the exception was denied where a federal prosecutor was listed as a state witness. ${ }^{114}$ Incredibly, in another case, the exception was denied although the deputy state attorney general was deputized to the Department of Justice as a Special Assistant U.S. Attorney and given responsibility for the federal prosecution while still on the state payroll! ${ }^{115}$ Indeed, some jurisdictions have questioned whether the sham prosecution exception exists at all. ${ }^{116}$

The emptiness of the sham prosecution exception is confirmed by the fact that cooperation between state and local and federal law enforcement authorities could scarcely be closer than it is today. In recent years, the level of cooperation between state and federal authorities has increased. ${ }^{117}$ Particular areas

108. Bartkus v. Ilinois, 359 U.S. 121, 124 (1959).

109. See, e.g., United States v. Bernhardt, 831 F.2d 181, 182 (9th Cir. 1987) (inferring existence of sham prosecution exception while rejecting existence of exception in case at bar). claim).

110. United States v. Aboumoussallem, 726 F.2d 906, 910 (2d Cir. 1984) (rejecting sham prosecution

111. Bernhardt, 831 F.2d at 182.

112. See supra text accompanying note 1 .

113. See United States v. Paiz, 905 F.2d 1014, 1024 (7th Cir. 1990) (sham prosecution claims have been "uniformly rejected" by 7th Circuit); United States v. Moore, 822 F.2d 35, 38 (8th Cir. 1987) (rejecting sham prosecution claim); Aboumoussallem, 726 F.2d 906 (2d Cir. 1984) (same); United States v. Liddy, 542 F.2d 76, $79-80$ (D.C. Cir. 1976) (same). An unappealed district court decision has found a sham prosecution, however. See United States v. Belcher, 762 F. Supp. 666 (W.D. Va.) (finding federal prosecution to be sham and cover for prior unsuccessful state prosecution), request for modification denied, 769 F. Supp. 201 (W.D. Va. 1991).

114. United States v. Aleman, 609 F.2d 298, 309 (7th Cir. 1979), cert. denied, 445 U.S. 946 (1980).

115. Bernhardt, 831 F.2d at 181.

116. See United States v. Patterson, 809 F.2d 244, 247 n.2 (5th Cir. 1987) (rejecting sham prosecution claim).

117. Close cooperation between state and federal authorities is not new, as Bartkus itself demonstrates. In Bartkus the Court upheld the validity of the dual sovereignty doctrine notwithstanding close cooperation between state and local investigative and prosecutorial authorities. See Bartkus v. Illinois, 359 U.S. 121, 164 (1959) (Brennan, J., dissenting on grounds that federal cooperation with state authorities was so extensive as to be prohibited by the Double Jeopardy Clause). Since Bartkus, courts have held that mere cooperation between state and federal authorities does not prevent application of the dual sovereignty doc- 
of law enforcement have assumed importance as elements of national policy. The creation of the national "drug czar" and the declaration of a "war on drugs" symbolize the elevation of narcotics enforcement to the level of national policy. Technological developments encourage increased cooperation between state and federal authorities, allowing them to share central databases and forensics laboratories. Financial constraints also encourage increased cooperation between state and federal authorities. Local agencies cannot afford to fight massive narcotics operations or white collar crime scandals without federal resources. The availability of federal civil and criminal forfeiture provisions ${ }^{118}$ and long mandatory minimum sentences ${ }^{119}$ also increase incentives for state authorities to cooperate with federal authorities.

Cooperation between state and federal authorities in enforcing narcotics laws has been particularly close. Even before the creation of a national "drug czar" and the declaration of "the war on drugs," there was extensive cooperation between state and federal agencies. This cooperation is authorized by statute. The Controlled Substances Act of $1970^{120}$ provides that "[ $[\mathrm{t}] \mathrm{he}$ Attorney General shall cooperate with local, State, and Federal agencies concerning traffic in controlled substances and in suppressing the abuse of controlled substances."121 To that end, the Attorney General is authorized to

- "arrange for the exchange of information"

- "cooperate in the ... prosecution of cases in the courts of the United States and before the licensing boards and courts of the several States"

- "conduct training programs ... for local, State, and Federal personnel" and

- maintain a central database through which local, state, and federal authorities can share information ${ }^{122}$

A 1986 amendment to the Act gave the Attorney General the power to "enter into contractual agreements with State and local law enforcement agencies to provide for cooperative enforcement and regulatory activities."123

In addition, under the forfeiture provisions of Title $21,{ }^{124}$ the Attorney General may transfer forfeited property to "any Federal agency or to any State or local law enforcement agency which participated directly in the seizure or forfeiture of the property."125 This authority is subject only to the conditions

trine. See, e.g., Moore, 822 F.2d at 38; Aleman, 609 F.2d at 309.

118. See, e.g., infra text accompanying notes 124-27.

119. See, e.g., Armed Career Criminal Act, 18 U.S.C. 924(e) (1988) (providing for imprisonment for fifteen years to life for possession of firearm by convicted felon).

120. Pub. L. 91-513, 84 Stat. 1242 (1970) (codified as amended in scattered sections of 21 U.S.C.).

121. 21 U.S.C. $\$ 873$ (a) (1981).

122. 21 U.S.C. $\S 873(\mathrm{a})(1)-(4)$ (1981).

123. 21 U.S.C. $\S 873(\mathrm{a})(7)$ (West Supp. 1991).

124. 21 U.S.C. $\S 881$ (1988).

125. 21 U.S.C. $\$ 881(\mathrm{e})(\mathrm{I})(\mathrm{A})(1988)$. 
that the transferred property "has a value that bears a reasonable relation to the degree of participation of the State or local agency in the law enforcement effort resulting in the forfeiture." 126 The authority is given for the purpose of "encourag[ing] further cooperation between the recipient State or local agency and federal law enforcement agencies."

Federal statutory authority is backed by federal financial resources, much of which is funneled to the states. President Bush requested $\$ 12.7$ billion to fight the "war on drugs" in fiscal 1993. ${ }^{128}$ In September of 1989, the Bush Administration's first National Drug Control Strategy "marked a new beginning in the federal government's war on drugs," a "coordinated, systematic national response to the problems posed by illicit drugs" in which "more than one in every four dollars [of the federal budget for drugs] . . . will go directly to the states." 129 Though some of the effort in the "war on drugs" is directed to treatment, education, and counseling programs, the bulk of the federal effort is directed to enforcement. The 1985 federal budget allocated $\$ 1.2$ billion for the drug law enforcement system, for example, as compared to $\$ 253$ million for drug abuse prevention and treatment programs. ${ }^{130}$

These financial resources have financed cooperative enforcement campaigns. Consider excerpts from a briefing by Attorney General Barr:

Starting early this morning, over 450 federal and state law enforcement officers started the execution of 38 search warrants and making arrests against members of the Rodrigues P Street Gang. . . . A few weeks ago, I said that because of our tough federal laws we're taking out violent gangs in one fell swoop. And these cases today are dramatic illustrations of how federal law enforcement can assist state and local law enforcement. ... And I would like to commend all the organizations that made these cases possible through their close cooperation. And they include the United States Park Police; the Drug Enforcement Administration; the Federal Bureau of Investigation; the [Immigration and Naturalization Service]; the [Bureau of Alcohol, Tobacco, and Firearms]; the Metropolitan Police Department in Washington, D.C.; the New York Police Department in Brooklyn, New York; the Arlington County Police Department; the Alexandria Police Department; and the coordinated efforts of the United States Attorneys Offices in the Eastern District of Virginia; in Washington, DC; in the Southern District of New York; the District of Colorado; and the District Attorney's Office for Kings County, Brooklyn, New York. ${ }^{131}$

126. 21 U.S.C. $\$ 881(\mathrm{e})(3)(\mathrm{A})(1988)$.

127. 21 U.S.C.A. \$ $881($ e)(3)(B) (West Supp. 1992).

128. Remarks by President George Bush Prior to News Conference Announcing 1992 National Drug Control Strategy, Federal News Service, Jan. 27, 1992, available in LEXIS, Nexis library.

129. Michael Levine, The Drug "War": Fight It at Home, N.Y. TIMES, Feb. 16, 1992, at A15. (1990).

130. STEVEN WISOTSKY, BEYOND THE WAR ON DRUGS: OVERCOMING A FAILED PUBLIC POLICY 61

131. Press Conference with Attorney General William Barr, Federal News Service, Jan. 31, 1992, available in LEXIS, Nexis library. 
Thus, state and federal law enforcement agencies often function as a unit, bound together by information, technology, financial incentives, contractual arrangements, and statutory mandate. ${ }^{132}$

It is clear, however, that even such extensive cooperation between federal and state law enforcement agencies will not lead to the demise of the dual sovereignty doctrine. So long as courts and commentators see the Double Jeopardy Clause solely as a device to protect individual rights, successive prosecutions by different sovereigns will continue.

Calls for the demise of the dual sovereignty doctrine must move beyond the argument that application of the Double Jeopardy Clause to the states renders the doctrine unconstitutional. Courts can easily justify the continued validity of the doctrine by pointing out that (1) the silver platter doctrine and related doctrines necessarily entailed cooperation, (2) the dual sovereignty doctrine theoretically does not, and (3) where state and federal authorities do cooperate, the sham prosecution exception to the dual sovereignty doctrine theoretically bars reprosecution. The illusory nature of the sham prosecution exception and the extensive nature of state and federal cooperation render this justification hollow but do not threaten the theoretical cogency of the dual sovereignty doctrine. An additional critique, from a structural perspective, is needed.

\section{Why the Dual Sovereignty Doctrine is Unconstitutional}

When the Double Jeopardy Clause is understood structurally, as implementing the principle of popular sovereignty, the unconstitutionality of the dual sovereignty doctrine becomes clear. The dual sovereignty doctrine is unconstitutional because it denigrates the principle of popular sovereignty underlying the Double Jeopardy Clause. An exercise of popular sovereignty is final and unappealable. Remember the words of James Wilson, "In all governments, whatever is their form, however they may be constituted, there must be a power established from which there is no appeal.... The only question is where that power is lodged? ... [I]t remains and flourishes with the people."133 Having invited the popular will to check its authority, government may not simply disregard it and try again. ${ }^{134}$

132. The dual sovereignty doctrine has been held not to apply where the relationship between polities is not independent and separate but dependent and cooperative. For example, the dual sovereignty doctrine does not permit successive prosecutions by city and state authorities. See Waller v. Florida, 397 U.S. 387 (1970). Nor does the doctrine permit successive prosecutions by tribal and federal authorities. See United States v. Wheeler, 545 F.2d 1255 (9th Cir. 1976).

133. WooD, supra note 22 at 133 (quoting James Wilson).

134. It should be noted that in declaring the dual sovereignty doctrine unconstitutional, this Note does not threaten concurrent state and federal legislative authority. Although the dual sovereignty doctrine was originally formulated to justify such concurrent authority, an expanding interpretation of the Commerce Clause rendered the dual sovereignty doctrine's justification of concurrent state and federal legislative authority obsolete. 
The protections of the Double Jeopardy Clause against successive prosecutions by different sovereigns apply not just to jury trials, but to plea bargains. Prosecutors and defendants bargain in the shadow of the jury. A prosecutor may offer a plea agreement because he or she may be uncertain of obtaining a conviction by a jury on the more serious charges. In such circumstances, a plea agreement to a lesser charge should carry the same consequences as an implicit acquittal by a jury on the more serious charge. ${ }^{135}$

In addition, the protections of the Double Jeopardy Clause against successive prosecutions by different sovereigns apply to bench trials. In conducting a bench trial, the judge takes the place of the jury. An acquittal or implicit acquittal by the judge should not, therefore, be subject to successive prosecution by a different sovereign. Although a defendant may waive his or her right to a jury trial, ${ }^{136}$ a defendant may not waive the applicability of a provision implementing the principle of popular sovereignty.

It is no defense of the dual sovereignty doctrine to argue that the principle of popular sovereignty is not denigrated because the second prosecution, like the first, would be before a jury and, therefore, subject to popular control. In addition to flouting the requirement that an exercise of popular sovereignty be unappealable - even to the people-this argument fails to recognize the procedural and strategic opportunities that a second trial presents the prosecution. For example, having conducted a "dry run," the prosecution has an opportunity to observe what evidence resonates with the jury. So informed, prosecutors will attempt to rebut that evidence at the second trial. That is precisely what happened in Bartkus. ${ }^{137}$ As another example, prosecutors may take advantage of jurors' awareness of the defendant's earlier prosecution. ${ }^{138}$

It is also no defense of the dual sovereignty doctrine to argue that without the doctrine, state courts may immunize defendants from federal prosecution. Chief Justice Taft recognized a fear that without the doctrine, "[i]f a State were to punish [a criminal act] by small or nominal fines, the race of offenders to the courts of that State to plead guilty and secure immunity from federal prosecution for such acts would not make for respect for the federal statute or for its deterrent effect."139 This fear is particularly troubling in the context of federal enforcement of the civil rights laws. This rationale cannot cure the constitutional defect in the dual sovereignty doctrine, however. Fortunately, the dual sovereignty doctrine is not needed to assuage Taft's fear. Federal courts

135. See supra text accompanying notes $47-48$.

136. See, e.g., Patton v. United States, 281 U.S. 276 (1930) (permitting waiver of jury trial in federal criminal court).

137. 359 U.S. 121, 166 (1959) (Brennan, J., dissenting).

138. See Heath v. Alabama, 474 U.S. 82 (1985) (upholding on dual sovereignty grounds a second trial for capital murder in Alabama following guilty plea to noncapital murder in Georgia even though jurors in Alabama trial were aware of defendant's guilty plea in Georgia proceeding).

139. United States v. Lanza, 260 U.S. 377, 385 (1922). 
have long refused to attach any precedential value to collusive suits. ${ }^{140}$ Therefore, state criminal convictions produced at the "stipulation of [the] parties" need not bar successive prosecution by federal authorities. As the Supreme Court wrote in Young v. United States, ${ }^{141}$

The public interest that a result be reached which promotes a wellordered society is foremost in every criminal proceeding. That interest is entrusted to our consideration and protection as well as to that of the enforcing officers. Furthermore, our judgments are precedents, and the proper administration of the criminal law cannot be left merely to the stipulation of parties. ${ }^{142}$

Finally, it is no defense of the dual sovereignty doctrine to argue that the principle of popular sovereignty is not denigrated because the second prosecution is before a different sovereign. This argument turns on the notion that, while the people are sovereign, there are many peoples in a federal republic. Under this notion, state juries represent the people of the state while federal juries represent the people of the United States. Successive prosecutions, the argument continues, do not denigrate the principle of popular sovereignty. On the contrary, successive prosecutions give each people an opportunity to speak. Under this argument, if the people are not one but many, successive prosecutions actually vindicate the principle of popular sovereignty. This argument supposes that a collection of citizens empaneled in a state courthouse is different in kind from a collection of citizens empaneled across the street in a federal courthouse. This supposition is spurious. Under the Constitution, state and federal trials must be held at comparable locations-in the state in which the crime occurred. ${ }^{143}$ State and federal juries must be drawn from the district in which the crime occurred. ${ }^{144}$ Finally, neither state nor federal jury selection processes may systematically exclude members of any cognizable class. ${ }^{145}$

Diehard dual sovereigntists might still contend that even though state and federal juries are drawn at comparable locations from the same populations, state and federal juries are not identical. The diehards might argue that jurors empaneled in a state court house will represent the people of the state while the very same jurors empaneled across the street in a federal court house will

140. See United States v. Johnson, 319 U.S. 302 (1943).

141. 315 U.S. 257 (1942).

142. Id. at 259.

143. See U.S. CONST. art. III, $\S 2$, cl. 3 (providing that "The trial of all crimes . . shall be held in the state where the said crimes shall have been committed").

144. U.S. Const. amend. VI (providing that "In all criminal prosecutions, the accused shall enjoy the right to a speedy and public trial, by an impartial jury of the State and district wherein the crime shall have been committed, which district shall have been previously ascertained by law").

145. Neal v. Delaware, 103 U.S. 370 (1881) (holding black defendant denied equal protection when tried before all white jury selected through ostensibly fair jury selection procedures); Strauder v. West Virginia, 100 U.S. 303 (1880) (holding black defendant denied equal protection when tried before all white jury selected through blatantly unfair jury selection procedures). 
represent the people of the United States. It is not clear, however, why those jurors would feel compelled to represent different sovereigns. On the contrary, the drafters of the Sixth Amendment seemed certain that jurors empaneled in a federal courthouse would represent the people of the state.

In one respect, the diehard dual sovereigntists may be right. Jurors of one state may represent a different "people" than jurors of another state. If so, the dual sovereignty doctrine might permit state prosecutions following prosecutions brought by another state. The Double Jeopardy Clause, even when understood structurally, does not forbid such prosecutions. Regulation of successive state prosecutions, therefore, must be left to individual states. As it happens, many states place some limitations on such prosecutions. ${ }^{146}$

\section{CONCLUSION}

The Double Jeopardy Clause is not simply a procedural safeguard afforded criminal defendants. The Clause is also a structural provision implementing the principle of popular sovereignty. Understood as such, the Double Jeopardy Clause bars federal prosecution of an offense that was the subject of an earlier state prosecution. Similarly, the Clause bars state prosecution of an offense that was the subject of an earlier federal prosecution. The dual sovereignty doctrine may continue to justify state prosecution of an offense that was the subject of an earlier prosecution by another state, however.

\section{POSTSCRIPT: AFTER THE SIMI VALLEY VERDICT}

As this Note neared publication, tragedy befell Los Angeles. ${ }^{147}$ Four white officers of the Los Angeles Police Department were charged in state court for criminal use of excessive force while arresting a black man. The trial was transferred from Los Angeles to Simi Valley, an area removed from inner-city Los Angeles and, perhaps, stocked with potential jurors ignorant of the racial hatred and brutal police practices that charge some urban environments. ${ }^{148}$ A Simi Valley jury acquitted the officers, notwithstanding videotaped evidence of the beating. Outraged by an apparently lawless verdict, some Los Angeles residents took to the streets and, through their own lawlessness, compounded the tragedy. The officers were subsequently indicted in federal court on charges arising from the same circumstances.

In the face of this tragedy, this Note attacks the very doctrine that permits federal authorities to reprosecute the Los Angeles Police officers. Given the depth of the tragedy, it is not enough to explain how this Note vindicates the

146. See supra text accompanying notes 94-97.

147. See generally Tom Mathews, The Siege of LA., NEwsweEk, May 11, 1992, at 20.

148. See Powell v. Superior Court of Los Angeles County, 232 Cal. App.3d 785 (1991) (directing trial court to grant defendants' motion for change of venue). 
principle of popular sovereignty underlying the Double Jeopardy Clause. It is also essential to explain how the Note contributes, in a small way, to a criminal justice system that is truly just.

While this Note limits its attack to the dual sovereignty doctrine, its implications are much wider in scope. An appreciation of the principle of popular sovereignty underlying the Constitution compels reconsideration of many of the procedural devices that emanate from the Bill of Rights. For example, a structural understanding of the vicinage and venue provisions of the Constitution may require reform of the rules governing change of venue. The vicinage and venue provisions may be understood as implementing the principle of popular sovereignty by ensuring that the power of a jury be wielded by people close to the facts and familiar with the context in which the alleged crime occurred ${ }^{149}$ Only a jury drawn from a populace knowledgeable of the circumstances in which the crime occurred can fulfill their role as a popular check on government authority.

Several jurisdictions are reconsidering the rules governing change of venue. ${ }^{150}$ For instance, shortly after the Los Angeles riots, a Florida state judge ordered the transfer of the trial of a Miami policeman from Orlando to Tallahassee. ${ }^{151}$ The judge reasoned that jurors in Tallahassee were more likely to share characteristics with the citizens of Miami (where the alleged crime occurred). ${ }^{152}$ This action is consistent with the analysis of this Note. Under that analysis, trials should be held before a populace that understands the context in which the alleged crime occurred. If the courts had adopted the full implications of this Note, the trial of the Los Angeles officers would not have been transferred to Simi Valley.

Remembering the structural purposes of the Bill of Rights is an awesome task, challenging us to rethink many of the procedural devices developed during the rights revolution. Full-scale reform of these devices will frighten some. Just as surely, piecemeal reform will frustrate others. The frightened should take comfort in the fact that full-scale reform reflects both the structure and the faith of the Constitution.

149. See U.S. CoNST. amend. VI (relating to vicinage); U.S. ConST. art. III, $\$ 2, \mathrm{cl} .3$ (relating to venue); Drew L. Kershen, Vicinage (pts. 1 \& 2), 29 OKLA. L. REV. 801 (1976), 30 OKLA. L. REV. 1 (1977) (demonstrating that Sixth Amendment imposes requirement that criminal juries be drawn from locality in which crime occurred). In the cautionary words of Joseph Story, the power of the jury should not be entrusted to those "incapable of estimating its worth, or ... too inert, or too ignorant, or too imbecile, to wield its optent armour." JOSEPH STORY, COMMENTARIES ON THE CONSTITUTION OF THE UNITED STATES 657 (Ronald D. Rotunda \& John E. Nowak ed., 1987).

150. See Mark Hansen, Different Jury, Different Verdict?, A.B.A. J., Aug. 1992, at 56 (describing proposed legislative reforms of change of venue law pending in New Jersey and California).

151. See Larry Rohter, Trial of a Miami Policeman in Death of Blacks is Moved, N.Y. TMME, May 7, 1992, at A23.

152. Id. 
